\title{
Therapeutic keratoplasty in Pseudomonas pyocyaneus corneal ulcers
}

\author{
S. R. K. MALIK AND GURBAX SINGH
}

Maulana Azad Medical College and Associated Irwin and G.B. Pant Hospital, New Delhi, Indid尺

Sloughing virulent corneal ulcers are still very common in India. Even with the bes: medication they often fail to respond and in such cases the eyes are invariably lost. This iso especially true in the case of ulcers caused by Pseudomonas pyocyaneus, when the clinicals course is so fulminating that only a bold and timely decision can save the eye. Kerato $-{ }_{\omega}$ plasty has been found to be a potent eye-saving procedure in 36 apparently hopeless cases of sloughing hypopyon corneal ulcer due to this organism seen in the corneal surgery unif in the years 1964 to 1969 .

\section{Material and methods}

Surgery was necessitated in these 36 cases for the following reasons : failure of medical treatment (10); perforated cornea (5), impending perforation (17), totally sloughed off cornea (4). The ages of the $3^{6}$ patients ranged from to to 60 years. In $3^{2}$ there was defective projection of light. Writtens consent for evisceration had been obtained before surgery, but it was decided that grafting could beo performed instead.

\section{TEGHNIQUE}

The method of cutting the graft varied according to the condition of the cornea.

\section{(a) Cases without corneal perforation}

The corneal trephine of appropriate diameter was adjusted to $0.5 \mathrm{~mm}$. depth and a deep groove was made in the cornea. A deep lamellar dissection was started and, if all infected tissue could be removed, a lamellar graft was applied. No attempt was made to drain the hypopyon.

In cases in which the graft bed was found to be involved after a deep lamellar dissection, penetrating keratoplasty was carried out. The anterior chamber was opened with the tip of a von Graefe catar-o act knife through the trephined groove. The button was cut away along the trephine mark by enlarging the puncture with the help of Castroviejo's corneal scissors.

(b) Cases with corneal perforation

A trephine groove of required size was made in the cornea to outline the part required for excision The blades of Castroviejo's corneal scissors were introduced through the perforation and taken $\omega$ radially to the edge of the groove in the host cornea. The cornea was excised along the line of the trephined groove.

Homografts were used in all cases, fresh donor tissue in 29 cases and glycerol-preserved tissue iṇ seven.

SURGERY (Figs I to 4 )

The operations were performed under general anaesthesia. The intraocular pressure was kept low by intravenous mannitol in thirty cases and by intravenous acetazolamide in six. For penetrating 
(

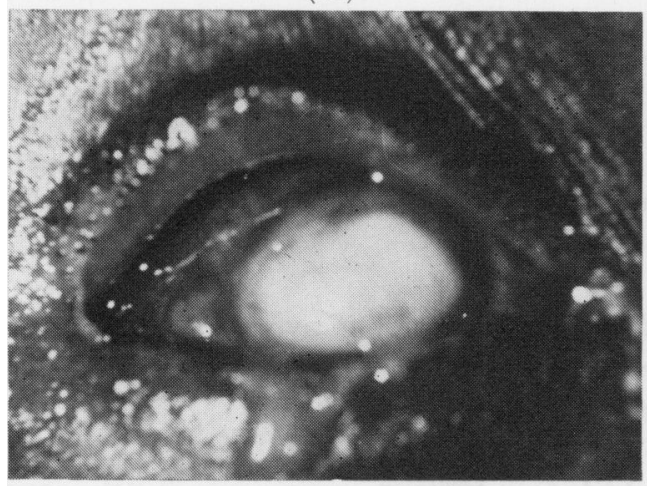

( $\mathrm{Ib}$

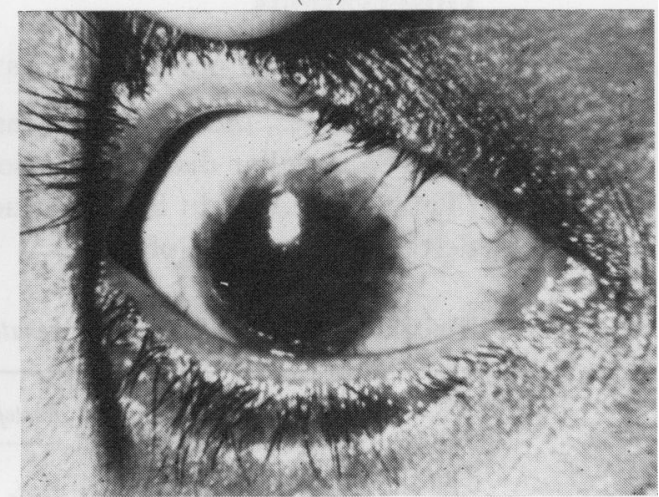

FIG. I (a) Preoperative appearance of sloughing Pseudomonas pyocyaneus corneal ulcer

FIG. I (b) Postoperative appearance, showing transparent graft after a $10 \mathrm{~mm}$. penetrating keratoplasty

(2a)

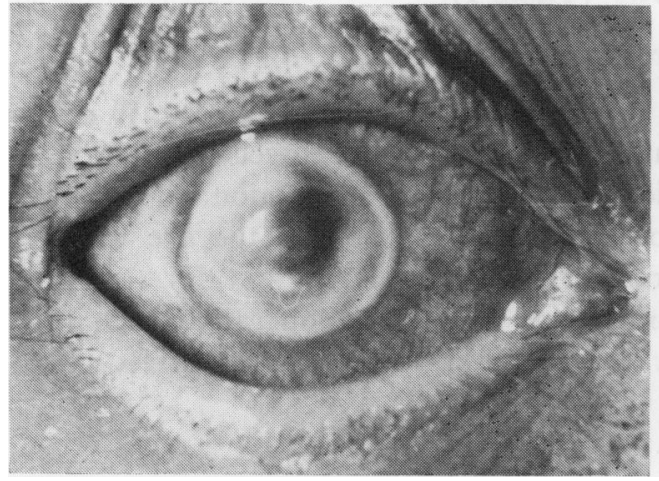

(2b)

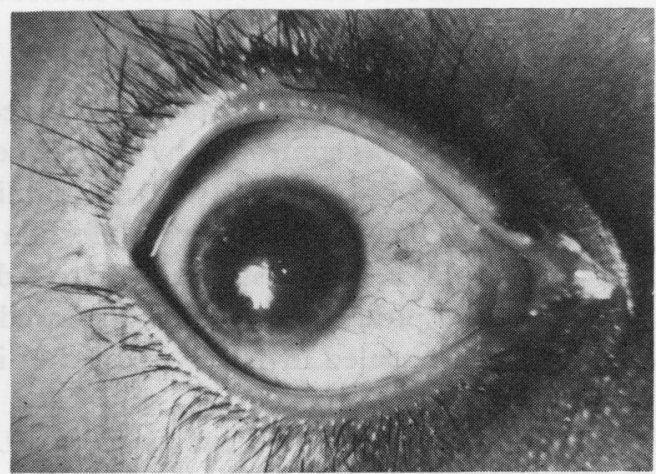

FIG. 2 (a) Appearance of total descemetocele with slough on borders

FIG. 2 (b) Clear ro mm. lamellar graft

grafts four peripheral iridectomies were performed, one in each quadrant. The anterior chamber was flushed continuously with sterile normal saline containing framycetin $(0.5 \mathrm{ml}$. in $20 \mathrm{ml}$. distilled water). Corneal sutures with $8-0$ virgin silk were placed $\mathrm{I} \cdot 5 \mathrm{~mm}$. apart to make the wound airtight. In suturing, the bite in the recipient side should be $1 \cdot 5^{-2} \mathrm{~mm}$. so that the needle does not cut through the oedematous edges.

\section{POSTOPERATIVE PROCEDURE}

A binocular bandage was applied for $24 \mathrm{hrs}$ in lamellar grafts and 6 days in penetrating grafts.

Postoperative intravenous injections of $275 \mathrm{mg}$. pyrolidinomethyl tetracycline were given 6-hrly for Io days. The patients also received acetazolamide $250 \mathrm{mg}$. 8-hrly, vitamin $\mathrm{G}$ I g. daily, and vitamin A 50,000 units daily. Framycetin eye ointment was applied daily, and neosporin and atropine ointment I per cent. were applied for I month. The sutures were removed on the 2 ist postoperative day. 
POSTOPERATIVE COMPLications (Table I)

Iritis was controlled by medical treatment in all cases.

The small punctate dots noted in the bed of the graft were due to residual infection. This was controlled by the frequent local instillation of framycetin eye drops in the immediate postoperative period in addition to the systemic medication.

Uncontrolled severe infection occurred in one case and the eye was lost although a total keratoplasty was performed on the second day.

Epithelial ulceration appeared in the 2 nd and 3 rd postoperative week in all eight cases; this healed in I to 2 weeks, but in one case lateral tarsorraphy was required.

\section{(B) PENETRATING KERATOPLASTy (Tables II and III)}

In 28 cases penetrating keratoplasty was performed as the infection had spread deep into the cornea or had caused perforation. In 25 cases there was defective projection of light. Four eyes were lost, three because of uncontrolled severe infection and one because of secondary glaucoma. In the seven cases in which preserved corneal tissue was used, the optical results were inferior to those in which fresh material was used.

Table II Result of penetrating keratoplasty in Pseudomonas pyocyaneus corneal ulcers (28 cases)

\begin{tabular}{|c|c|c|c|c|c|c|c|c|c|c|c|c|c|}
\hline \multirow{2}{*}{$\begin{array}{l}\text { Donor } \\
\text { tissue }\end{array}$} & \multirow{2}{*}{$\begin{array}{l}\text { Size of } \\
\text { graft } \\
(\mathrm{mm} .)\end{array}$} & \multirow{2}{*}{$\begin{array}{l}\text { Total } \\
\text { no. of } \\
\text { cases }\end{array}$} & \multirow{2}{*}{$\begin{array}{l}\text { Initial } \\
\text { faulty } \\
\text { projection } \\
\text { of light }\end{array}$} & \multicolumn{4}{|c|}{ Postoperative complications } & \multirow{2}{*}{$\begin{array}{l}\text { Rein- } \\
\text { fection }\end{array}$} & \multirow{2}{*}{$\begin{array}{l}\text { Epithelial } \\
\text { ulcer }\end{array}$} & \multicolumn{4}{|c|}{ Final visual acuity } \\
\hline & & & & Iritis & $\begin{array}{l}\text { Anterior } \\
\text { synechiae }\end{array}$ & $\begin{array}{l}\text { Glau- } \\
\text { coma }\end{array}$ & $\begin{array}{l}\text { Cata- } \\
\text { ract }\end{array}$ & & & $<6 / 60$ & $6 / 60$ & $6 / 18$ & $6 / 12$ \\
\hline \multirow[t]{4}{*}{ Fresh } & 8 & 7 & 4 & 7 & 4 & - & - & - & $\mathbf{I}$ & 3 & - & 4 & - \\
\hline & 9 & 3 & 3 & 3 & I & I & I & - & - & 3 & - & - & - \\
\hline & Io & 5 & 5 & 5 & 3 & - & - & - & 5 & I & 4 & - & - \\
\hline & II & 6 & 6 & 6 & 2 & - & I & - & 6 & 2 & I & 2 & 1 \\
\hline \multirow{2}{*}{$\begin{array}{l}\text { Glycerol- } \\
\text { preserved }\end{array}$} & 10 & I & I & $\mathbf{I}$ & - & - & - & I & I & - & - & - & - \\
\hline & I I & 6 & 6 & 6 & - & - & - & 2 & 6 & 4 & - & - & - \\
\hline
\end{tabular}


POSTOPERATIVE GOMPLications (Table II)

The mild to moderate iritis seen in all cases was controlled by medical treatment.

Anterior synechiae were observed in ten cases and anterior synechiotomy was carried out in six cases during the third postoperative week.

Epithelial ulceration occurred in twenty cases. One out of ten cases with small grafts and all eighteen cases with grafts of 10 or I I $\mathrm{mm}$. developed epithelial ulcers. Seventeen cases improved with med cal treatment, and the other three healed with lateral tarsorraphy.

Table III Final result of keratoplasty in Pseudomonas pyocyaneus corneal ulcers

\begin{tabular}{|c|c|c|c|c|c|c|c|c|c|}
\hline \multirow{2}{*}{ Types of keratoplasty } & \multirow{2}{*}{$\begin{array}{l}\text { Total no. } \\
\text { of cases }\end{array}$} & \multirow{2}{*}{$\begin{array}{l}\text { Structural } \\
\text { improvement }\end{array}$} & \multirow{2}{*}{$\begin{array}{l}\text { Eye } \\
\text { lost }\end{array}$} & \multicolumn{6}{|c|}{ Final visual acuity } \\
\hline & & & & $6 / 12$ & $6 / 18$ & $6 / 24$ & $6 / 36$ & $6 / 60$ & $<6 / 60$ \\
\hline 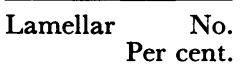 & $\begin{array}{r}8 \\
100\end{array}$ & $87 \cdot 5$ & $\begin{array}{l}1 \\
12 \cdot 5\end{array}$ & $\begin{array}{l}- \\
-\end{array}$ & $\begin{array}{r}2 \\
25\end{array}$ & $\begin{array}{r}2 \\
25\end{array}$ & $\begin{array}{c}1 \\
12 \cdot 5\end{array}$ & $\begin{array}{r}2 \\
25\end{array}$ & - \\
\hline $\begin{array}{r}\text { Penetrating No. } \\
\text { Per cent. }\end{array}$ & $\begin{array}{r}28 \\
100\end{array}$ & $\begin{array}{l}24 \\
85 \cdot 7\end{array}$ & $\begin{array}{c}4 \\
14 \cdot 3\end{array}$ & $\begin{array}{l}\text { I } \\
3.57\end{array}$ & $\begin{array}{c}6 \\
21 \cdot 42\end{array}$ & - & $\begin{array}{l}- \\
-\end{array}$ & $\begin{array}{c}5 \\
17 \cdot 8\end{array}$ & $\begin{array}{l}12 \\
42 \cdot 9\end{array}$ \\
\hline
\end{tabular}

\section{Discussion}

Pseudomonas pyocyaneus is probably the most virulent organism causing sloughing corneal ulcers and is often responsible for panophthalmitis. It is found in the gastrointestinal tract and is a common contaminant of fluorescein solutions, so that some cases result from the use of contaminated solutions when removing corneal foreign bodies. Streptomycin, polymyxin B, Colestin, framycetin, and some of the newer broad-spectrum antibiotics may be helpful in some cases if used promptly and vigorously.

Unfortunately most of these cases come to us late after they have developed faulty projection of light or corneal perforation. It is well known that defective projection of light is a sign of impending panophthalmitis in cases of sloughing corneal ulcer, and such eyes have previously been eviscerated, though the lens and vitreous were afterwards found to be healthy.

Sporadic reports of the use of lamellar keratoplasty in such cases have been found in the literature (Coppez, I949; Paufique, I950; Molnar, I96o; Ricci, 1964; Stein and Lazar, 1964). Gallenga (1950) achieved structural improvement in all his eight cases and visual improvement in four.

Seven out of eight eyes in our series were saved by lamellar keratoplasty, and although improvement in visual acuity was hardly expected it was achieved in seven cases in which the final result was $6 / 18$ to $6 / 60$.

There are only a few reports of penetrating keratoplasty. Löhlein (I950) saved twelve out of thirteen eyes. Paufique and Philps (1950) achieved a visual acuity 6/9 in one early case, and Ricci ( 1964 ) and Hallerman ( 1967 ) also had structural successes.

In the present series, 85.7 per cent. of eyes were saved which otherwise would have been eviscerated, and the final acuity ranged from $6 / 60$ to $6 / 12$ in 39.2 per cent. of cases (Table III).

It is surprising that these corneal ulcers showed such a good response even with large penetrating grafts. Many surgeons fear that the infection will spread and become virulent if the anterior chamber is opened, but we found that the infective process was halted. This may occur for a number of reasons, such as the removal of infected tissue and its 
replacement by fresh tissue resistant to infection and the antibacterial properties of fresh aqueous.

The complications were unexpectedly few. The incidence of secondary glaucoma was low, probably because of the multiple iridectomies. The incidence of anterior synechiae was not as high as seen in optical grafts of more than $8 \mathrm{~mm}$., probably because of the adherence of the iris to the anterior surface of the lens.

\section{Summary}

Therapeutic keratoplasty (8 lamellar and 28 penetrating) was performed in 36 apparently hopeless cases of Pseudomonas pyocyaneus corneal ulcers. The surgical procedure, postoperative complications, and structural and visual results are described.

\section{References}

COPPEZ, L. (1949) Ann. Oculist. (Paris), 182, 597

GAllenga, R. (1950) Rass. ital. ottal., 19, 3

hallerman, w. (1967) Surv. Ophthal., 12, 490

LÖHLEIN, W. (1950) v. Graefes Arch. Ophthal., 15I, I

MOLNAR, L. (1960) Ibid., 162, I

PaufiQue, L. (1950) Amer. F. Ophthal., 33, no. 3, pt 2, p. 24

- and PHILPs, s. (1950) Brit. F. Ophthal., 34, 746

RICGI, A. (1964) Ophthalmologica (Basel), 147, 259

STEIN, R., and LAZAR, M. (1964) Ibid., 148, 425 